\title{
Juxtaposition of Coeliac Disease and Type 1 Diabetes; the Role of Shared Non-human Leukocyte Antigen Loci
}

\author{
Iraj Shahramian' ${ }^{1}$, Hossein Shahdadi ${ }^{2}$, Ali Bazi ${ }^{3,4^{*}}$, Nosratollah Masinaeinezhad ${ }^{3}$, Mojtaba Delaramnasab ${ }^{3,4}$ \\ ${ }^{1}$ Pediatric Ward, Amir-Al-Momenin Hospital, Zabol University of Medical Sciences, Zabol, Iran \\ ${ }^{2}$ Faculty of Nursing, Zabol University of Medical Sciences, Zabol, Iran \\ ${ }^{3}$ Faculty of Allied Medical Sciences, Zabol University of Medical Sciences, Zabol, Iran \\ ${ }^{4}$ Clinical Research Development Unit, Amir-Al-Momenin Hospital, Zabol University of Medical Sciences, Zabol, Iran
}

\section{*Correspondence to Ali Bazi, Clinical Research Development Unit, Amir-Al- Momenin Hospital, Zabol University of Medical Sciences, Zabol, Iran Tel/Fax: +985432239031; Email: m.bazilai@gmail.com}

Received December 23, 2017 Accepted February 24, 2018 Published online March 31, 2018

\begin{abstract}
Although extensive studies have been performed to explore the role of various alleles within the human leukocyte antigen (HLA) in susceptibility to coeliac disease (CD) and type 1 diabetes (T1D), less attention has been dedicated to the role of shred non-HLA loci. In the present report, we have provided a review on the role of genetic variants in seven shared non-HLA loci in determining the risk of either CD orT1D. The literature search was done on the Web of Knowledge, PubMed, and Scopus databases using keywords of polymorphism, coeliac disease, and type 1 diabetes. The literature published within 2000-2017 were recruited. Seven discussed shared loci between $\mathrm{CD}$ and T1D were those resided within cytotoxic T-lymphocyte associated protein 4 (CTL4), regulator of G protein signaling (RGS1), SH2B adaptor protein (SH2B3), T cell activation Rho GTPase activating protein (TAGAP), interleukin 18 receptor accessory protein (IL18RAP), protein tyrosine phosphatase, non-receptor type (PTPN2), and C-C motif chemokine receptor (CCR5). The interaction between polymorphisms of these genes seems to exert a substantial impact on determining the risk of CD and T1D in context of each other. Polymorphisms residing in these loci can exert synergistic or opposing effects toward either protection or predisposition to $\mathrm{CD}$ and T1D. The majority of these polymorphisms affect the function of cytokine signaling or T cell activating pathways. The net outcome deems to be delineated by a complex interaction between these adaptor arms, as well as the modulatory effects of other components of immune system, in particular, HLA alleles.

Keywords: Coeliac disease, Type 1 diabetes, Single nucleotide polymorphism, Human leukocyte antigen
\end{abstract}

association rate than general population.

Progression of $\mathrm{CD}$ in the context of T1D can exaggerate and complicate the clinical course T1D. In fact, T1D patients with concurrent $\mathrm{CD}$ have presented higher propensity for cardiovascular complications, metabolic disorders, renal insufficiency, and retinopathy. ${ }^{4-7}$ Based on these, it is of critical importance to divulge risk factors of CD in the context of T1D.

Genetic susceptibility is a main factor in predicting the risk of various human diseases, including both CD and T1D. Among these genetic loci are human leukocyte antigen (HLA) genes. In fact, HLA-DQ2 and HLA-DQ8 are 2 well-

(c) 2018 The Author(s); Published by Zabol University of Medical Sciences. This is an open-access article distributed under the terms of the Creative Commons Attribution License (http://creativecommons.org/licenses/by/4.0), which permits unrestricted use, distribution, and reproduction in any medium, provided the original work is properly cited. 
known shared risk factors for both CD and T1D. Nearly all patients with CD reveal either HLA-DQ2 (95\%) or HLA-DQ8 (5\%) upon HLA typing. ${ }^{8,9}$ Interestingly, HLADQ alleles are also mapped in nearly one-third of T1D cases. Overall, inheritance of certain HLA alleles has been well established to be associated with the risk of CDT1D coexistence. Although the role of HLA loci has been extensively evaluated in risk association studies, there are few remarks on the impact of non-HLA genetic loci in determining the risk of CD and T1D co-development. In the present review, we have focused on a number of proposed shared non-HLA genetic loci and their possible interactions in determining the risk of either CD or T1D.

\section{Search Strategy}

A comprehensive search was done on the Web of Knowledge, PubMed, and Scopus databases using keywords of polymorphism, coeliac disease, and type 1 diabetes. The star; “*” truncation was applied as " $\mathrm{C}^{\star}$ eliac" to recruit differentially spelled forms in Web of Knowledge and Scopus. Time spans included literature published within 2000-2017, and those assessed one of the shared genetic loci reported by Smyth et al. ${ }^{10}$

\section{Shared Non-HLA Loci Between CD and T1D}

Until recently, 42 non-HLA genes loci have been identified to modulate the risk and progression of the CD. ${ }^{11}$ Among these, 7 shared loci have been proposed between CD and T1D so far (Table 1). ${ }^{10}$ In the following sections, we have discussed the potential role of these shared loci in determining the risk of $\mathrm{CD}$ and T1D development.

\section{Cytotoxic T-Lymphocyte Associated Protein 4}

Up to date, there have been about 100 polymorphic loci identified at the locus of cytotoxic T-lymphocyte associated protein 4 (CTL4) gene at chromosome $2 \mathrm{q} 33$. Some polymorphisms residing in CTLA4 locus (i.e. SNPs of CT60 G>A (rs3087243) and AG49 (rs231775)) have been correlated with lower levels of CTLA-4. The rs5742909 $(-318 \mathrm{C} / \mathrm{T})$ is another polymorphism located in the promoter region of CTLA-4 gene. Nevertheless, no significant impact was identified for this variant with neither $\mathrm{CD}^{12}$ nor T1D.27

The role of CT60 G>A (rs3087243) polymorphism has been noted in some autoimmune disorders. ${ }^{40-43}$ Reports of the impact of this polymorphism on protective or predisposing effects toward either CD and T1D have been conflicting. Smyth et al have considered a protective role for this polymorphism against both CD and T1D. ${ }^{10}$ However, others have asserted a predisposing impact for this polymorphism for either $\mathrm{CD}^{12}$ or T1D. ${ }^{13-15}$ However, the susceptibility toward T1D has been noted for the wild-type allele at this locus. ${ }^{13-15}$ Based on this, one can comprehend a parallel protective role for the minor allele (A) of this locus as noted in the study of Smyth et al. $^{10}$ Based on a proposed recessive mode for this polymorphism, general idea is that only homozygous wild-type combination of rs3087243 is associated with elevated risk for autoimmunity. ${ }^{40}$ In fact, $G$ allele of this polymorphism has been associated with depressed expression of CTLA- $4 .{ }^{44}$

Inheritance of rs231775 ( $+49 \mathrm{~A} / \mathrm{G})$ polymorphism was shown to be linked to dampen levels of CLTA4 in both plasma and cell surface of $\mathrm{T}$ lymphocytes. ${ }^{45}$ These reduced levels, which subsequently lead to lower immunomodulatory effects of CTLA-4, have been accompanied with a higher rate of autoimmune conditions such as T1D, Graves disease, and graft rejection in transplanted individuals. ${ }^{46,47}$ Multiple studies have noted predisposing role for minor $\mathrm{G}$ allele of this polymorphism for $\mathrm{CD}^{18}$ and T1D. ${ }^{13-15,19-24}$ Two studies; Mora et al, Naluai et $\mathrm{al}^{16,17}$ have observed the higher risk of CD in individuals bearing the wild-type A allele of this polymorphism. On the other hand, some have not reported any significant association between this polymorphism with the occurrence of $\mathrm{CD}^{12,13}$ and T1D. ${ }^{25,26}$ Synergistic effects of CT60 G>A and +49 A/G polymorphisms of CTLA4 gene has been noted as a dominant risk factor for the development of polyglandular autoimmunity $(\mathrm{OR}=4.89$, 95\% CI: 1.86-13.59)..$^{40}$

Inheritance of two $G$ alleles at the +49 locus within CTLA-4 gene result in a low functional index of CTLA4. Nevertheless, individuals with homozygote signature for A allele may also develop autoimmune conditions indicating a multidisciplinary interaction for detraining risk of autoimmunity. ${ }^{45}$ Actually, immune reactions are dependent on a complex interaction of non-HLA loci mediators with those of HLA II alleles. This is substantially important as HLA II molecules impart a significant role in antigen presentation to reactive $\mathrm{T}$ lymphocytes.

The function of $\mathrm{T}$ lymphocytes is negatively regulated by CTLA-4. Therefore, low activity of this molecule results in deregulated activation of $\mathrm{T}$ lymphocytes predisposing to autoimmune disorders. In fact, the use of immune checkpoint inhibitors (ICIs); ipilimumab (antiCTLA-4), which has been proposed as an immunotherapy approach in malignancies, has been debated due to the possibility of an increased rate of autoimmune disorders. ${ }^{48,49}$ This molecule functionally belongs to immunoglobulin proteins and is highly detectable on the surface of $\mathrm{T}$ lymphocytes. In particular, CTLA-4 is identifiable in considerable copy numbers on the surface of regulatory $\mathrm{T}$ lymphocytes $(\mathrm{CD} 4+\mathrm{CD} 25+\mathrm{FoxP} 3+)$ and also cytotoxic activated $\mathrm{T}$ cells. ${ }^{50,51}$ Recently, it has been proposed that regulatory $\mathrm{T}$ cells prevent autoimmune reactions through inhibition of dendritic cells (DCs) in a CTLA-4 dependent way. ${ }^{52}$ CTLA- 4 has been noted to counterbalance the signaling pathways originated form activator complexes on the surface of activated $\mathrm{T}$ lymphocytes namely CD28-B7. In fact, both CTLA4 and $\mathrm{CD} 28$ are ligands for $\mathrm{B} 7$ family receptors on $\mathrm{T}$ lymphocyte membrane. However, CTLA-4 and CD28 
Table 1. Shared Non-HLA Loci Associated With Both Celiac Disease and Type 1 Diabetes in Children

\begin{tabular}{|c|c|c|c|c|c|}
\hline $\begin{array}{l}\text { Non-HLA Loci } \\
\text { (Chromosome } \\
\text { Location) }\end{array}$ & SNP & $\begin{array}{l}\text { Effector } \\
\text { Allele }\end{array}$ & Effects & Celiac Disease & Type 1 Diabetes \\
\hline \multirow[t]{5}{*}{ CTLA-4, 2q33.2 } & rs3087243 (CT60 G>A) & A & Pro & Smyth et $\mathrm{al}^{10}$ & Smyth et al ${ }^{10}$ \\
\hline & & & Sus & Song et $\mathrm{al}^{12}$ & $\begin{array}{l}\text { Dallos et al, Jin et al, Wang et } \\
\text { al }^{13-15 b}\end{array}$ \\
\hline & rs231775 ( +49 A/G) & G & Sus & $\begin{array}{l}\text { Mora et al, Naluai et } \mathrm{al}^{16,17,}, \mathrm{c} \\
\text { El-Akawi et } \mathrm{al}^{18}\end{array}$ & $\begin{array}{l}\text { Dallos et al, Jin et al, Wang et } \\
\text { al (2014), Wang et al (2017), } \\
\text { Li et al, Ranjouri et al, Si et al, } \\
\text { Mosaad et al, Reddy et al }{ }^{13-} \\
15,19-24\end{array}$ \\
\hline & & & Ns & Song et $\mathrm{al}^{12}{ }^{12}$ Dallos et $\mathrm{al}^{13}$ & Celmeli et al, Tavares et $\mathrm{al}^{25,26}$ \\
\hline & rs5742909 (-318 C/T) & $\mathrm{T}$ & Ns & Song et $\mathrm{al}^{12}$ & Almasi et $\mathrm{al}^{27}$ \\
\hline \multirow[t]{3}{*}{ TAGAP, 6q25.3 } & rs1738074 & A & Pro & - & Smyth et $\mathrm{al}^{10}$ \\
\hline & & & Sus & Romanos et $\mathrm{al}^{28}$ & - \\
\hline & & & Ns & Amundsen et al, Plaza-Izurieta et $\mathrm{al}^{29,30}$ & - \\
\hline \multirow[t]{3}{*}{ IL-18RAP, $2 q 12.1$} & rs2816316 & G & Pro & - & Smyth et al ${ }^{10}$ \\
\hline & rs917997 & $A$ & Sus & Amundsen et al, Plaza-Izurieta et $\mathrm{a}^{29,30}$ & - \\
\hline & rs13015714 & G & Ns & Amundsen et $\mathrm{al}^{30}$ & - \\
\hline \multirow[t]{5}{*}{ PTPN2, 18p11.21 } & rs478582 & G & Pro & Smyth et al ${ }^{10}$ & Smyth et al ${ }^{10}$ \\
\hline & & & Ns & - & Peng et $\mathrm{al}^{31}$ \\
\hline & rs2542151 & G & Pro & - & Peng et al ${ }^{31}$ \\
\hline & rs45450798 & G & Sus & Smyth et al ${ }^{10}$ & Smyth et al ${ }^{10}$ \\
\hline & rs1893217 & $\mathrm{C}$ & Ns & 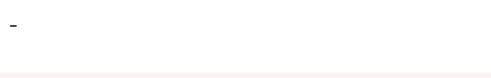 & $\begin{array}{l}\text { Reddy et al, Rheinheimer et } \\
\text { al } 24,32\end{array}$ \\
\hline \multirow[t]{2}{*}{ RGS1, $1 \mathrm{q} 31.2$} & rs2816316 & $\mathrm{C}$ & Pro & $\begin{array}{l}\text { Amundsen et al, Romanos et al, Guo et al, } \\
\text { Plaza-Izurieta et } \mathrm{al}^{28-30,33}\end{array}$ & - \\
\hline & & & Sus & - & Parkkola et al ${ }^{34}$ \\
\hline \multirow[t]{2}{*}{$\mathrm{SH} 2 \mathrm{~B} 3,12 \mathrm{q} 24.12$} & rs3184504 & $\mathrm{T}$ & Sus & Romanos et al, Guo et al 28,35 & $\begin{array}{l}\text { Smyth et al, Reddy et al, Steck } \\
\text { et al, Nikitin et al }{ }^{10,24,36,37}\end{array}$ \\
\hline & & & Ns & Plaza-Izurieta et al ${ }^{29}$ & - \\
\hline \multirow[t]{2}{*}{ CCR5, 3p21.31 } & $\begin{array}{l}\text { rs333 (Delta } 32 \\
\text { polymorphism- 32-bp }\end{array}$ & - & Pro & Smyth et al ${ }^{10}$ & $\begin{array}{l}\text { Smyth et al, Słomiński et al, } \\
\text { Buhler et al }{ }^{10,38,39}\end{array}$ \\
\hline & & & Sus & Słomiński et al 38 & - \\
\hline
\end{tabular}

Abbreviation: SNP; single nucleotide polymorphism, Pro; protection, Sus; susceptibility, Ns; no significant effect; CTLA-4, cytotoxic T-lymphocyte associated protein 4; TAGAp, T cell activation Rho GTPase activating protein; SH2B3, SH2B adaptor protein; IL-18RAP, interleukin 18 receptor accessory protein; RGS1, regulator of G protein signaling; CCR5, C-C motif chemokine receptor; PTPN2, protein tyrosine phosphatase non-receptor type.

a Selection of these shared loci are based on the report of Smyth et al, $2008{ }^{10}$

b Susceptibility associated with G allele.

Susceptibility associated with A allele.

competitivity bind and negatively and positively regulate $\mathrm{T}$ cell function respectively. ${ }^{44,53}$ Signaling pathways activated by the CTLA- 4 was shown to induce tolerance against the development of autoimmune conditions. ${ }^{54}$ In vitro blockage of CTLA-4/B7 complexes suppressed the proliferative activity of $\mathrm{T}$ lymphocytes in response to mitotic stimulators. The mechanisms for inhibitory effects of CTLA-4 are not fully understood, however, hindering from formation of CD28/B7 stimulatory complexes has been observed as a potential factor.
Regulator of G Protein Signaling

This molecule belongs to the family of regulator of G-protein signaling (RGS). The risk of some autoimmune disorders, including T1D, has been higher in carriers of polymorphism within RGS1 gene. The function of RGS1 is critical for recruitment of lymphocytic population into the lymphoid organ. This is achieved by modulation of chemokine receptor functions; CCR7 and CXCR4, by RGS1. ${ }^{55-57}$ Through its potent GTPase activity, RGS1 suppresses signaling pathways originated form 
chemokine receptors. In fact, RGS1 degrades G-proteins which are mandatory downstream messengers for cellular signaling activities. ${ }^{58}$ There are multiple reports indicating a significant protection against $\mathrm{CD}$ in individuals bearing the $\mathrm{C}$ allele of rs2816316 polymorphism mapped on RGS1 gene. ${ }^{28-30,33}$ In contrast, inheritance of this variant has been noted in association with a higher chance of being affected with T1D. ${ }^{34}$

\section{SH2B Adaptor Protein}

As for the genetic loci in the previous section, $\mathrm{SH} 2 \mathrm{~B}$ adaptor protein (SH2B3) also modulates signaling pathways derived from inflammatory cytokines and suppresses the proliferative activity of $\mathrm{B}$ and $\mathrm{T}$ lymphocytes. ${ }^{59,60}$ In particular, $\mathrm{SH} 2 \mathrm{~B} 3$ is a master regulator of the intracellular interaction of signaling adaptors participating in inflammatory reactions. ${ }^{61}$ Due to the presence of conserved $\mathrm{SH} 2$ domain, these variant molecules of $\mathrm{SH} 2 \mathrm{~B} 3$ can inhibit formation and interaction of the NOD2 intracellular receptor and modulate ERK1/2 and p38MAPK pathways. ${ }^{62}$ Importance of the rs3184504 polymorphism within $\mathrm{SH} 2 \mathrm{~B} 3$ is highlighted as carriers of the minor allele $(\mathrm{T})$ at this locus are more prone to both $\mathrm{CD}^{28,35}$ and T1D. ${ }^{10,24,36,37}$

\section{T Cell Activation Rho GTPase Activating Protein}

A single polymorphism (rs1738074), a variation mapped within the 5 -UTR region of the T cell activation Rho GTPase activating protein (TAGAP)gene, was noted to confer a protection against T1D. ${ }^{10}$ Complementary to this, Romanos et al described an elevated risk of $\mathrm{CD}$ in individuals with minor (A) allele of this polymorphism. In contrast, Amundsen et al and Plaza-Izurieta et al stated no impacts regarding inheritance of this genetic variant with susceptibility to CD. ${ }^{29,30}$

Polymorphisms within TAGAP, located at 6q25, have been accompanied by various autoimmune diseases including CD. ${ }^{63}$ As mentioned for RGS1, TAGAP also acts as an activator for GTPase functionality within cells. Nevertheless, TAGAP activates a specific GTPase unique for RhoA molecule which is merely expressed within activated T lymphocytes. ${ }^{64,65}$ Especially, TAGAP activation is critical in cytoskeleton rearrangements and migration of T lymphocytes. ${ }^{66}$ Furthermore, TAGAP also binds RhoH; a molecule which interacts with Lck and ZAP70 molecules downstream to T cell receptor (TCR) cytoplasmic domain. Through this, TAGAP precludes ZAP70 from interacting with $\mathrm{RhoH}$ and suppresses TCR signaling. ${ }^{64}$ Recently, TAGAP has been proposed as a potential target for induction of Th17 lymphocytes which are modulatory populations against autoimmune disorders. ${ }^{64}$

Interleukin 18 Receptor Accessory Protein

Interleukin 18 receptor accessory protein (IL18RAP) is one component of heterodimeric IL-18R. The other subunit of this receptor is known as IL18R1. This complex is highly detectable on the surface of immune cells including $\mathrm{T}$ lymphocytes. During $\mathrm{T}$ cell activation and particularly in response to IL-12, IL-18RAP is activated and contributes to intracellular signaling pathways in lymphocytes. ${ }^{67}$

Polymorphisms within the IL18RAP seem to exert antithetical roles in the development of CD and T1D. While rs2816316 ( $\mathrm{G}$ minor allele) polymorphism was identified to protects against T1D, an elevated risk of CD has been described for carriers of rs917997 polymorphism. $^{29,30}$ On the other hand, rs917997 polymorphism has been described as a protective factor against T1D while a risk factor for CD in another report. ${ }^{68}$ The rs917997, a polymorphism located in the 3' UTR, has been accompanied by depressed levels of IL18RAP in the serum of individuals with CD. ${ }^{62,69}$ Another polymorphism of this gene, rs13015714 was not found to exert a significant influence on the occurrence of $\mathrm{CD} .{ }^{30}$

\section{Protein Tyrosine Phosphatase Non-receptor Type}

Smyth et $\mathrm{al}^{10}$ have drawn conflicting conclusions regarding the role of 2 polymorphisms of this gene; rs478582 and rs45450798, regarding their protective and predisposing roles for CD respectively. In the same report, these researchers also found parallel effects of these polymorphisms regarding T1D (i.e. a protective role for rs478582 and a predisposing role for rs45450798). ${ }^{10}$ Furthermore, Peng et al have noted lower odds for development of T1D in subjects with minor $(G)$ allele of rs2542151 polymorphism of protein tyrosine phosphatase non-receptor type (PTPN2) gene. ${ }^{31}$ In 2 additional reports, no significant association was reported between rs1893217 polymorphism of PTPN2 gene with T1D. ${ }^{24,32}$ The majority of polymorphic sites within PTPN2 reside with intronic regions. ${ }^{70}$ These variants are supposed to give rise to alternative splicing sites resulting in altered stability of mRNA or non-sense frameshifts as well as epigenetic consequences, which all lead to altered bioavailability of the protein. ${ }^{65}$

Both T1D and gastrointestinal disorders such as inflammatory bowel disease, Crohn disease as well as autoimmune disorders such as rheumatoid arthritis have been noted in association with polymorphisms within non-coding regions of PTPN2. ${ }^{71-73}$ As for some of the previously mentioned loci, PTPN2 is also closely related to regulation of cytokine signaling. ${ }^{74}$ PTPN2 belongs to a family of dephosphorylating enzymes breaking phosphates from tyrosine residues within the cytoplasmic domain of cytokine receptors. ${ }^{75}$ Regarding functional activity, PTPN2 is particularly important in the regulation of T lymphocytes toward both self and foreign antigens. ${ }^{76}$ Aberration of PTPN2 gene in animal models has been linked to higher susceptibility to autoimmune reactions in various organs such as kidney, skin, pancreas, and liver. ${ }^{76}$ This observation has been accompanied by promoted 
activities of T and B lymphocytes as well as higher levels of proinflammatory cytokines. ${ }^{76}$

\section{C-C Motif Chemokine Receptor}

$\mathrm{C}-\mathrm{C}$ motif chemokine receptor (CCR5) is involved in the recruitment of immune cells, including innate immunity cells such as $\mathrm{T}$ lymphocytes, to inflamed tissues. CCR5 is particularly bound to chemokine ligand 5 , an attractant expressed by $\mathrm{T}$ lymphocytes, macrophage inflammatory protein-1, and monocyte chemoattractant protein-2. ${ }^{77}$ A common genetic variant of CCR5, a 32 base pair deletion (rs333, 32-bp deletion), has been widely studied as a functional polymorphism within this gene. Homozygosity for this variant has been associated with dim expression of CCR5 on the cell membrane. ${ }^{78}$ Smyth et $\mathrm{al}^{10}$ and Słomiński et $\mathrm{al}^{39}$ declared conflicting results regarding the impact of this polymorphic variant of CCR5 gene in the progression of CD (protective vs. predisposing respectively). In studies on T1D patients, however, multiple reports have stipulated a protective role for this polymorphism. ${ }^{10,38,39,79,80}$

\section{Conclusion}

Immune disorders are associated with aberrant regulation of immune functions. T1D and CD are two common forms of autoimmune diseases concomitantly observed in the considerable ratio of individuals. Although HLA loci play an important role in the determination of susceptibility to either $\mathrm{CD}$ and $\mathrm{T} 1 \mathrm{D}$, the role of shared non-HLA loci is less characterized. It seems that interaction of polymorphic variants of genes involved in regulation of immune cell activities, in particular $\mathrm{T}$ lymphocytes, with each other and with HLA loci to be critical in determining the risk of T1D and CD in the context of each other. Large population-based studies are warranted to explore the role of these loci in future studies.

\section{Ethical Approval \\ Not applicable.}

\section{Competing interest}

None.

\section{References}

1. Shahramian I, Dehghani SM, Haghighat $M$, et al. Serologic evaluation of celiac disease in patients with beta thalassemia major and control. Gastroenterol Hepatol Bed Bench. 2015;8(2):153-159.

2. Naderi M, Shahramian I, Delaramnasab M, Bazi A. Coincidence of celiac disease with nongastrointestinal tumors in children. Pediatr Hematol Oncol. 2017;34(8):478482. doi:10.1080/08880018.2017.1404171

3. Noori NM, Shahramian I, Dehghani SM, et al. Evaluation of Celiac Disease in Children with Dilated Cardiomyopathy. Int Cardiovasc Res J. 2017;11(1):e10562.
4. Assa A, Frenkel-Nir Y, Tzur D, Katz LH, Shamir R Cardiovascular Risk Factors in Adolescents With Celiac Disease: A Cross-sectional Population-Based Study. J Pediatr Gastroenterol Nutr. 2017;65(2):190-194. doi:10.1097/mpg.0000000000001487

5. Salardi S, Maltoni G, Zucchini S, et al. Celiac Disease Negatively Influences Lipid Profiles in Young Children With Type 1 Diabetes: Effect of the Gluten-Free Diet. Diabetes Care. 2016;39(8):e119-120. doi:10.2337/dc160717

6. Kurien M, Mollazadegan K, Sanders DS, Ludvigsson JF. Celiac Disease Increases Risk of Thyroid Disease in Patients With Type 1 Diabetes: A Nationwide Cohort Study. Diabetes Care. 2016;39(3):371-375. doi:10.2337/ dc15-2117

7. Weiss B, Pinhas-Hamiel O. Celiac Disease and Diabetes: When to Test and Treat. J Pediatr Gastroenterol Nutr. 2017;64(2):175-179. doi:10.1097/mpg.0000000000001388

8. Ludvigsson JF, Ludvigsson J, Ekbom A, Montgomery SM. Celiac disease and risk of subsequent type 1 diabetes: a general population cohort study of children and adolescents. Diabetes Care. 2006;29(11):2483-2488. doi:10.2337/dc06-0794

9. Tye-Din JA, Cameron DJ, Daveson AJ, et al. Appropriate clinical use of human leukocyte antigen typing for coeliac disease: an Australasian perspective. Intern Med J. 2015;45(4):441-450. doi:10.1111/imj.12716

10. Smyth DJ, Plagnol V, Walker NM, et al. Shared and distinct genetic variants in type 1 diabetes and celiac disease. N Engl J Med. 2008;359(26):2767-2777. doi:10.1056/ NEJMoa0807917

11. Dubois PC, Trynka G, Franke L, et al. Multiple common variants for celiac disease influencing immune gene expression. Nat Genet. 2010;42(4):295-302. doi:10.1038/ ng. 543

12. Song GG, Kim JH, Kim YH, Lee YH. Association between CTLA-4 polymorphisms and susceptibility to Celiac disease: a meta-analysis. Hum Immunol. 2013;74(9):12141218. doi:10.1016/j.humimm.2013.05.014

13. Dallos T, Avbelj M, Barak L, et al. CTLA-4 gene polymorphisms predispose to autoimmune endocrinopathies but not to celiac disease. Neuro Endocrinol Lett. 2008;29(3):334-340.

14. Jin P, Xiang B, Huang G, Zhou Z. The association of cytotoxic T-lymphocyte antigen- $4+49 \mathrm{~A} / \mathrm{G}$ and CT60 polymorphisms with type 1 diabetes and latent autoimmune diabetes in Chinese adults. J Endocrinol Invest. 2015;38(2):149-154. doi:10.1007/s40618-0140162-x

15. Wang J, Liu L, Ma J, Sun F, Zhao Z, Gu M. Common variants on cytotoxic $\mathrm{T}$ lymphocyte antigen- 4 polymorphisms contributes to type 1 diabetes susceptibility: evidence based on 58 studies. PLoS One. 2014;9(1):e85982. doi:10.1371/ journal.pone. 0085982

16. Naluai AT, Nilsson S, Samuelsson L, et al. The CTLA4/CD28 gene region on chromosome $2 \mathrm{q} 33$ confers susceptibility to celiac disease in a way possibly distinct from that of type 1 diabetes and other chronic inflammatory disorders. Tissue Antigens. 2000;56(4):350-355. doi:10.1034/j.13990039.2000.560407.x 
17. Mora $\mathrm{B}$, Bonamico $\mathrm{M}$, Indovina $\mathrm{P}$, et al. CTLA- $4+49$ $\mathrm{A} / \mathrm{G}$ dimorphism in Italian patients with celiac disease. Hum Immunol. 2003;64(2):297-301. doi:10.1016/s01988859(02)00782-6

18. El-Akawi ZJ, Mansour AS. The Role of Cytotoxic T-Lymphocyte Associated Antigen 4 (CTLA4) +49A/G and Tumor Necrosis Factor Alpha (TNF-\&alpha;) -308G/ A Polymorphism in the Development of Celiac Disease in Jordanian Patients. J Health Sci. 2010;56(1):41-46. doi:10.1248/jhs.56.41

19. Wang B, Du W, Jia Y, Zhang X, Ma G. Cytotoxic T-lymphocyte-associated protein $4+49 \mathrm{~A} / \mathrm{G}$ polymorphisms contribute to the risk of type 1 diabetes in children: An updated systematic review and meta-analysis with trial sequential analysis. Oncotarget. 2017;8(6):1055310564. doi:10.18632/oncotarget.14457

20. Li YY, Gong G, Geng HY, Yang ZJ, Zhou CW, Lu XZ. CTLA- $4+49 \mathrm{~A} / \mathrm{G}$ gene polymorphism and type 1 diabetes mellitus in the Chinese population: a meta-analysis of 2238 subjects. Int J Diabetes Dev Ctries. 2016;36(1):45-51. doi:10.1007/s13410-015-0414-0

21. Ranjouri MR, Aob P, Mansoori Derakhshan S, Shekari Khaniani M, Chiti H, Ramazani A. Association study of IL2RA and CTLA4 Gene Variants with Type I Diabetes Mellitus in children in the northwest of Iran. Bioimpacts. 2016;6(4):187-193. doi:10.15171/bi.2016.25

22. Si X, Zhang X, Luo Y, Tang W. Association between the CTLA-4 $+49 \mathrm{~A} / \mathrm{G}$ polymorphism and type 1 diabetes: a meta-analysis. Genet Test Mol Biomarkers. 2012;16(11):1336-1342. doi:10.1089/gtmb.2012.0169

23. Mosaad YM, Elsharkawy AA, El-Deek BS. Association of CTLA-4 $(+49 \mathrm{~A} / \mathrm{G})$ gene polymorphism with type 1 diabetes mellitus in Egyptian children. Immunol Invest. 2012;41(1):28-37. doi:10.3109/08820139.2011.579215

24. Reddy MV, Wang H, Liu S, et al. Association between type 1 diabetes and GWAS SNPs in the southeast US Caucasian population. Genes Immun. 2011;12(3):208-212. doi:10.1038/gene.2010.70

25. Celmeli F, Turkkahraman D, Ozel D, Akcurin S, Yegin O. CTLA-4 $(+49 \mathrm{~A} / \mathrm{G})$ polymorphism and type-1 diabetes in Turkish children. J Clin Res Pediatr Endocrinol. 2013;5(1):40-43. doi:10.4274/Jcrpe.879

26. Tavares NA, Santos MM, Moura R, et al. Association of TNF-alpha, CTLA4, and PTPN22 polymorphisms with type 1 diabetes and other autoimmune diseases in Brazil. Genet Mol Res. 2015;14(4):18936-18944. doi:10.4238/2015. December.28.42

27. Almasi S, Aliparasti MR, Aliasgarzadeh $\mathrm{A}$, et al. Investigation of CTLA-4-318C/T gene polymorphism in cases with type 1 diabetes of Azerbaijan, Northwest Iran. Immunol Lett. 2015;166(2):134-139. doi:10.1016/j. imlet.2015.05.021

28. Romanos J, Barisani D, Trynka G, Zhernakova A, Bardella MT, Wijmenga C. Six new coeliac disease loci replicated in an Italian population confirm association with coeliac disease. J Med Genet. 2009;46(1):60-63. doi:10.1136/ jmg.2008.061457

29. Plaza-Izurieta L, Castellanos-Rubio A, Irastorza I, Fernandez-Jimenez N, Gutierrez G, Bilbao JR. Revisiting genome wide association studies (GWAS) in coeliac disease: replication study in Spanish population and expression analysis of candidate genes. J Med Genet. 2011;48(7):493-496. doi:10.1136/jmg.2011.089714

30. Amundsen SS, Rundberg J, Adamovic S, et al. Four novel coeliac disease regions replicated in an association study of a Swedish-Norwegian family cohort. Genes Immun. 2010;11(1):79-86. doi:10.1038/gene.2009.67

31. Peng H, Li J, Chen X, Zhou X, Zhu W, Li F. Genetic Variants of PTPN2 Gene in Chinese Children with Type 1 Diabetes Mellitus. Med Sci Monit. 2015;21:2653-2658. doi: $10.12659 / \mathrm{msm} .893607$

32. Rheinheimer J, Oliveira Fdos S, Canani LH, Crispim D. The rs1893217 (T/C) polymorphism in PTPN2 gene is not associated with type 1 diabetes mellitus in subjects from Southern Brazil. Arq Bras Endocrinol Metabol. 2014;58(4):382-388. doi:10.1590/0004-2730000003050.

33. Guo CC, Wang M, Cao FD, et al. Meta-Analysis on Associations of RGS1 and IL12A Polymorphisms with Celiac Disease Risk. Int J Mol Sci. 2016;17(4):457. doi:10.3390/ijms 17040457

34. Parkkola A, Laine AP, Karhunen M, et al. HLA and nonHLA genes and familial predisposition to autoimmune diseases in families with a child affected by type 1 diabetes. PLoS One. 2017;12(11):e0188402. doi:10.1371/journal. pone. 0188402

35. Guo CC, Huang WH, Zhang N, et al. Association between IL2/IL21 and SH2B3 polymorphisms and risk of celiac disease: a meta-analysis. Genet Mol Res. 2015;14(4):1322113235. doi:10.4238/2015.October.26.19

36. Steck AK, Xu P, Geyer S, et al. Can Non-HLA Single Nucleotide Polymorphisms Help Stratify Risk in TrialNet Relatives at Risk for Type 1 Diabetes? J Clin Endocrinol Metab. 2017;102(8):2873-2880. doi:10.1210/jc.2016-4003

37. Nikitin AG, Lavrikova EY, Seregin YA, et al. Association of the polymorphisms of the ERBB3 and SH2B3 genes with type 1 diabetes. Mol Biol. 2010;44(2):228-232. doi:10.1134/ s002689331002007x

38. Słomiński B, Lawrynowicz U, Mysliwska J, et al. CCR5Delta 32 gene polymorphism is related to celiac disease and autoimmune thyroiditis coincidence in patients with type 1 diabetes. J Diabetes Complications. 2017;31(3):615618. doi:10.1016/j.jdiacomp.2016.10.031

39. Buhler MM, Craig M, Donaghue KC, et al. CCR5 genotyping in an Australian and New Zealand type 1 diabetes cohort. Autoimmunity. 2002;35(7):457-461. doi:10.1080/0891693021000041088

40. Houcken J, Degenhart C, Bender K, Konig J, Frommer L, Kahaly GJ. PTPN22 and CTLA-4 Polymorphisms are Associated with Polyglandular Autoimmunity. J Clin Endocrinol Metab. 2018. doi:10.1210/jc.2017-02577

41. Ni J, Qiu LJ, Zhang M, et al. CTLA-4 CT60 (rs3087243) polymorphism and autoimmune thyroid diseases susceptibility: a comprehensive meta-analysis. Endocr Res. 2014;39(4):180-188. doi:10.3109/07435800.2013.879167

42. Rodriguez A, Alfaro JM, Balthazar V, Pineda Trujillo N. Association analysis of PTPN22, CTLA4 and IFIH1 genes with type 1 diabetes in Colombian families. J Diabetes. 2015;7(3):402-410. doi:10.1111/1753-0407.12192

43. Torres-Carrillo N, Ontiveros-Mercado H, TorresCarrillo NM, et al. The $-319 \mathrm{C} /+49 \mathrm{G} / \mathrm{CT} 60 \mathrm{G}$ haplotype of CTLA-4 gene confers susceptibility to rheumatoid arthritis in Mexican population. Cell Biochem Biophys. 
2013;67(3):1217-1228. doi:10.1007/s12013-013-9640-6

44. Ueda H, Howson JM, Esposito L, et al. Association of the T-cell regulatory gene CTLA4 with susceptibility to autoimmune disease. Nature. 2003;423(6939):506-511. doi:10.1038/nature01621

45. Kouki T, Sawai Y, Gardine CA, Fisfalen ME, Alegre ML, DeGroot LJ. CTLA-4 gene polymorphism at position 49 in exon 1 reduces the inhibitory function of CTLA- 4 and contributes to the pathogenesis of Graves' disease. J Immunol. 2000;165(11):6606-6611.

46. Donner H, Rau H, Walfish PG, et al. CTLA4 alanine-17 confers genetic susceptibility to Graves' disease and to type 1 diabetes mellitus. J Clin Endocrinol Metab. 1997;82(1):143-146. doi:10.1210/jcem.82.1.3699

47. Martin TM, Bye L, Modi N, et al. Genotype analysis of polymorphisms in autoimmune susceptibility genes, CTLA-4 and PTPN22, in an acute anterior uveitis cohort. Mol Vis. 2009;15:208-212.

48. Day D, Hansen AR. Immune-Related Adverse Events Associated with Immune Checkpoint Inhibitors. BioDrugs. 2016;30(6):571-584. doi:10.1007/s40259-016-0204-3

49. Joshi M, Pal SK, Drabick JJ. Novel approaches in cancer immunotherapy -- a light at the end of the tunnel. Discov Med. 2016;21(118):479-487.

50. Wing $\mathrm{K}$, Onishi Y, Prieto-Martin P, et al. CTLA-4 control over Foxp3+ regulatory $\mathrm{T}$ cell function. Science. 2008;322(5899):271-275. doi:10.1126/science.1160062

51. Radenkovic M, Silver C, Arvastsson J, et al. Altered regulatory $\mathrm{T}$ cell phenotype in latent autoimmune diabetes of the adults (LADA). Clin Exp Immunol. 2016;186(1):4656. doi:10.1111/cei.12834

52. Alissafi T, Banos A, Boon L, et al. Tregs restrain dendritic cell autophagy to ameliorate autoimmunity. J Clin Invest. 2017;127(7):2789-2804. doi:10.1172/jci92079

53. Greenfield EA, Nguyen KA, Kuchroo VK. CD28/B7 costimulation: a review. Crit Rev Immunol. 1998;18(5):389418.

54. Tokic S, Stefanic M, Karner I, Glavas-Obrovac L. Altered expression of CTLA-4, CD28, VDR, and CD45 mRNA in T cells of patients with Hashimoto's thyroiditis - a pilot study. Endokrynol Pol. 2017;68(3):274-828. doi:10.5603/ ep.2017.0020

55. Moratz C, Harrison K, Kehrl JH. Regulation of chemokineinduced lymphocyte migration by RGS proteins. Methods Enzymol. 2004;389:15-32. doi:10.1016/s00766879(04)89002-5

56. Reif K, Cyster JG. RGS molecule expression in murine B lymphocytes and ability to down-regulate chemotaxis to lymphoid chemokines. J Immunol. 2000;164(9):47204729.

57. Caballero-Franco C, Kissler S. The autoimmunityassociated gene RGS1 affects the frequency of T follicular helper cells. Genes Immun. 2016;17(4):228-238. doi:10.1038/gene.2016.16

58. Oldham WM, Hamm HE. Heterotrimeric G protein activation by G-protein-coupled receptors. Nat Rev Mol Cell Biol. 2008;9(1):60-71. doi:10.1038/nrm2299

59. Pawson T. Specificity in signal transduction: from phosphotyrosine-SH2 domain interactions to complex cellular systems. Cell. 2004;116(2):191-203.
60. Devalliere J, Charreau B. The adaptor Lnk (SH2B3): an emerging regulator in vascular cells and a link between immune and inflammatory signaling. Biochem Pharmacol. 2011;82(10):1391-1402. doi:10.1016/j.bcp.2011.06.023

61. Windheim M, Lang C, Peggie M, Plater LA, Cohen P. Molecular mechanisms involved in the regulation of cytokine production by muramyl dipeptide. Biochem J. 2007;404(2):179-190. doi:10.1042/bj20061704

62. Zhernakova A, Elbers CC, Ferwerda B, et al. Evolutionary and functional analysis of celiac risk loci reveals $\mathrm{SH} 2 \mathrm{~B} 3$ as a protective factor against bacterial infection. Am J Hum Genet. 2010;86(6):970-977. doi:10.1016/j.ajhg.2010.05.004

63. Arshad M, Bhatti A, John P. Identification and in silico analysis of functional SNPs of human TAGAP protein: A comprehensive study. PLoS One. 2018;13(1):e0188143. doi:10.1371/journal.pone.0188143

64. Tamehiro N, Nishida K, Yanobu-Takanashi R, Goto M, Okamura T, Suzuki H. T-cell activation RhoGTPaseactivating protein plays an important role in TH17-cell differentiation. Immunol Cell Biol. 2017;95(8):729-735. doi:10.1038/icb.2017.27

65. Mao M, Biery MC, Kobayashi SV, et al. T lymphocyte activation gene identification by coregulated expression on DNA microarrays. Genomics. 2004;83(6):989-999. doi:10.1016/j.ygeno.2003.12.019

66. Jazaeri A, Vallian S. Association of rs1738074 polymorphism of TAGAP gene with susceptibility to multiple sclerosis in the Iranian population. Neurosci Lett. 2017;648:66-69. doi:10.1016/j.neulet.2017.03.041

67. Yoshimoto T, Takeda K, Tanaka T, et al. IL-12 up-regulates IL-18 receptor expression on T cells, Th1 cells, and $\mathrm{B}$ cells: synergism with IL-18 for IFN-gamma production. J Immunol. 1998;161(7):3400-3407.

68. Myhr CB, Hulme MA, Wasserfall $\mathrm{CH}$, et al. The autoimmune disease-associated SNP rs917997 of IL18RAP controls IFNgamma production by PBMC. J Autoimmun. 2013;44:8-12. doi:10.1016/j.jaut.2013.06.001

69. Hunt KA, Zhernakova A, Turner G, et al. Newly identified genetic risk variants for celiac disease related to the immune response. Nat Genet. 2008;40(4):395-402. doi:10.1038/ng.102

70. Maurano MT, Humbert R, Rynes E, et al. Systematic localization of common disease-associated variation in regulatory DNA. Science. 2012;337(6099):1190-1195. doi:10.1126/science.1222794

71. Houtman M, Shchetynsky K, Chemin K, et al. T cells are influenced by a long non-coding RNA in the autoimmune associated PTPN2 locus. J Autoimmun. 2018. doi:10.1016/j. jaut.2018.01.003

72. Todd JA, Walker NM, Cooper JD, et al. Robust associations of four new chromosome regions from genome-wide analyses of type 1 diabetes. Nat Genet. 2007;39(7):857-864. doi: $10.1038 /$ ng 2068

73. Sharp RC, Abdulrahim M, Naser ES, Naser SA. Genetic Variations of PTPN2 and PTPN22: Role in the Pathogenesis of Type 1 Diabetes and Crohn's Disease. Front Cell Infect Microbiol. 2015;5:95. doi:10.3389/fcimb.2015.00095

74. Doody KM, Bourdeau A, Tremblay ML. T-cell protein tyrosine phosphatase is a key regulator in immune cell signaling: lessons from the knockout mouse model 
and implications in human disease. Immunol Rev. 2009;228(1):325-341. doi:10.1111/j.1600-065X.2008.00743.x

75. Cerosaletti K, Buckner JH. Protein tyrosine phosphatases and type 1 diabetes: genetic and functional implications of PTPN2 and PTPN22. Rev Diabet Stud. 2012;9(4):188-200. doi:10.1900/rds.2012.9.188

76. Wiede F, Sacirbegovic F, Leong YA, Yu D, Tiganis T. PTPN2-deficiency exacerbates $\mathrm{T}$ follicular helper cell and $\mathrm{B}$ cell responses and promotes the development of autoimmunity. J Autoimmun. 2017;76:85-100. doi:10.1016/j.jaut.2016.09.004

77. Cheng FJ, Zhou XJ, Zhao YF, Zhao MH, Zhang H. Chemokine receptor 5 (CCR5) delta 32 polymorphism in lupus nephritis: a large case-control study and metaanalysis. Autoimmunity. 2014;47(6):383-388. doi:10.3109/ 08916934.2014.906581

78. Liu R, Paxton WA, Choe S, et al. Homozygous defect in HIV-1 coreceptor accounts for resistance of some multiply-exposed individuals to HIV-1 infection. Cell. 1996;86(3):367-377. 